\title{
THE INFLUENCE OF INTEREST AND MOTIVATION ON COLLGE STUDENTS' LANGUAGE AND ART APPRECIATION LEARNING OUTCOMES
}

\author{
Risa Triarisanti ${ }^{1}$, Pupung Purnawarman ${ }^{2}$ \\ Korean Education Program ${ }^{1}$; English Education Department ${ }^{2}$ \\ Universitas Pendidikan Indonesia \\ Bandung, Indonesia \\ risatriarisanti@upi.edu
}

First draft received: 23 Oct 2018 Date Accepted: 31 Dec 2018 Final proof received: 22 Feb 2019

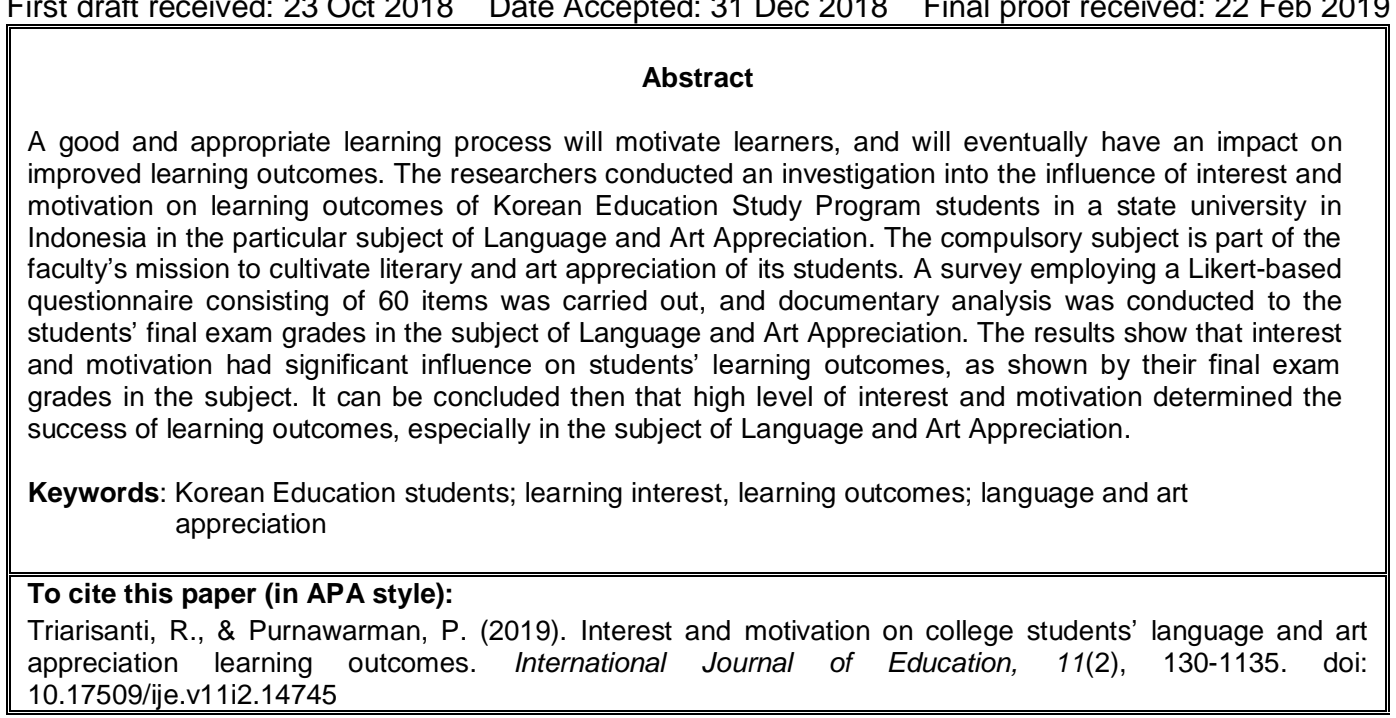

\section{INTRODUCTION}

Learning outcomes are the most important factor in learning, because they can describe the state of learners in understanding the material delivered by lecturers (Tella, 2007). Learning outcomes can be measured directly with numbers as well as seen in their daily life practices (Asim, Chase, Dar, \& Schmillen, 2016). Low student learning outcomes indicate that learners have not mastered the material well. Teachers usually only point out the errors of the learner's work without telling the correct answer so that learners will possibly repeat the same mistakes while working on similar questions. Such conditions are difficult to improve learning outcomes (O'Neil, Wainess, \& Baker, 2005).

According to Biggs (2012), the factors that affect learning can be classified into two, namely internal factors which include physical, psychological, and fatigue, and external factors, including family, community, and school. Sari (2009) affirmed the effectiveness of learning behavior is influenced by motivation, interest, effort, and evaluation. Interest and learning outcomes are intertwined. Interest in learning contributes greatly to the success of learners (Slameto, 2010). This fact is also reinforced by Sardiman's opinion (2011) that the learning process will run smoothly when accompanied by interest. Likewise, according to Burke (1995) interest in learning is a major factor that determines the learning activities of learners. Motivational factors can also affect learning outcomes. Sadirman (2011) also puts forward a similar argument regarding motivational factors. He argues that the learning outcomes will be optimal if there is motivation in the students. A good and appropriate learning process will motivate students to learn, which will in turn have an impact on improving learners' learning outcomes (Hanrahan, 2000).

There have been many studies on the topics of motivation, interest, and learning outcomes. Bye, Pushkar, and Conway (2007) found that motivation and interest had positive effect on traditional and nontraditional undergraduate students. Similarly, Eom, Wen, and Ashill (2006) revealed that motivation is one of the six variables that can affect learning outcomes. Muller \& Louw (2004) investigated the relationship among learning environment, motivation and interest. 


\section{Triarisanti E Purnawarman}

The results showed that intrinsic factors (interest, motivation, confidence) and extrinsic factors (teachers, curriculum) affect the learning outcomes.

The present study would like to contribute to the existing research by focusing on the simultaneous influence of learning motivation and interest on college students' learning outcomes of language and art appreciation subject. The subject of language and art appreciation is one of the compulsory courses in the faculty of language and literature education at which the researchers teach and conducted the present study. The teaching of this subject is intended to promote students' appreciation of arts and language. As most of the students in the faculty are students of the language program/department, the emphasis of the course has been on the language students' ability to appreciate art, although of course language appreciation is also cultivated. Students generally will show their appreciation and even stage arts performance with audiences from outside the class, namely other students and lecturers from other programs/departments in the faculty, or even large audiences. Students who do not really have skills in arts will have to have high interest and motivation in order to pass the class. Hence, it will be interesting to see the extent to which their learning outcomes in this subject are influenced by motivation and interest in learning arts.

Learning Outcomes, Interest, and Motivation in the Subject of Language and art appreciation

Learning theories underlying the practice of education are born from three schools of psychology: Behavioristic Psychology, Cognitivistic, and Humanistic Psychology. These three streams are derived from the philosophical point of view of John Locke and Leibnitz (in Burke, 1995).

According to Wenger (1997), there are some principles of learning, including: a) learning must have a purpose; b) the goals must relate to the needs of life; c) there must be effort and willingness to experience various difficulties in the learning process; d) there must be a change of behavior; e) it must consist of sideline and main purposes; f) learning should be done by doing; g) learning should be holistic; h) there are elements of help and guidance of others; i) requirement of attention (insight); j) there are other goals in addition to the actual purpose; k) learning is said to succeed when yielding in success; and I) repetition and practice need to be given on the basis of understanding, $\mathrm{m}$ ) there is a willingness to learn (motivation).

High interest in learning, as argued by Hidi \& Renninger (2006), will greatly affect the way learners learn; for example a learner who wants to get good learning outcomes, will learn earnestly by focusing on the lesson. Thus, a high interest in learning will affect the process of successful teaching and learning activities. This is especially important in language and art appreciation subject for language and literature students. The language major students will have to show learn arts appreciation, which is not their background or concentration of study. Hence, they will have to be interested in arts and the subject in general in order to obtain satisfactory learning outcomes.

In essence, interest in learning creates immediate attention, facilitates concentration, prevents distraction, strengthens the attachment to learning materials, and reduces the boredom of learning. High learning interest is expected to help learners get high learning results as well (Silvia, 2008). Silvia (2008) adds that there are some indicators that show learners' interest in learning, such as interest in reading books, attention in learning, learners' activity in learning, and knowledge. These indicators will be used in identifying learning interest of the students under research.

Another factor determining the success of learning is motivation (Cheak \& Wessel, 2005). According to the theory of human needs, motivation in learning refers to the ability to meet the needs (Maslow, 1955). Motivation is a mental drive that moves, directs attitudes and individual actors in learning (Harun, 2006). Motivation is found in the ideals or aspirations of learners. These ideals or aspirations are expected so that learners can learn and understand the goal in learning and can selfactualize themselves.

As argued by Ormrod (2006), motivation has an influence on learners' learning behavior, which encourages increased enthusiasm and perseverance in learning. In particular, passion, enthusiasm and a sense of fun in learning can generate high motivation so that learners will have a lot of energy to carry out learning activities and will eventually be able to obtain good achievement (Ormrod, 2006)

Hamalik (2005) divides motivation into intrinsic and extrinsic ones, and both are influenced by several factors such as the level of self-awareness of learners of the needs that encourage behavior/action and awareness of learning objectives to be achieved. As stated by Warumu (2006), the elements that influence learning motivation are aspirations of the soul, the ability of learners, the condition of learners, the environmental conditions of learners, the dynamic elements in learning and learning and efforts of educators in learning learners.

Less successful learners tend to have selfmotivated difficulties such as lack of purpose, verbal reinforcement, and self-control (Sogunro, 2014). This argument is reinforced by other researchers such as Dansereau (1969) and Frankola et al. (2010) who opine that strong motivation will tend to be more successful in learning than in poor motivation.

Apart from the feeling of pleasure and attention, to know whether or not a learner's interest in a lesson can be seen from the knowledge that the learner has. Learners who are interested in a lesson will have broad knowledge of the lessons and get benefits from learning in everyday life.

Interest and motivation, hence, are two of the many factors that influence learning outcomes. The higher interest and motivation of students, the higher learning outcomes will be. Conversely, the lower the 
interest and motivation, the lower the learning outcomes. Herein, the researchers would like to see whether learning interest and motivation have influence on learning outcomes of the students in language and art appreciation subject.

\section{METHOD}

Based on the problems and objectives that have been formulated, this study used a survey method, highlighting the existence of inter-variables using the framework and followed by formulating a hypothesis (Fahrmeir, Pigeot, Künstler, \& Tutz, 2004).

\section{Population and Sample}

The population in this research included the first generation of Korean Education study program students, batch 2015, consisting of 53 students, further divided into 27 students from class $A$ and 26 students from class $B$

In this research, random sampling was carried out in order to get equal number of subjects. The sampling technique was drawn upon Yamane (1973), as follow: $\mathrm{n}=\mathrm{N} /(\mathrm{N} \cdot \mathrm{d} 2+1)$

Description:

$\mathrm{n}=$ number of samples

$\mathrm{N}=$ total population

$\mathrm{d} 2=$ specified precision

Using the above formula and the precision level set at $5 \%$, then the sample of the population was determined as follows:

$$
\begin{aligned}
\mathrm{n} & =\mathrm{N} /(\mathrm{N} . \mathrm{d} 2+1) \\
& =53 /(53(0.05) 2+1) \\
& =53 /(53(0.0025)+1) \\
& =53 / 1.1325 \\
& =46.799117
\end{aligned}
$$

Based on the above calculation, the minimum sample used was as many as 47 out of 53 students.

After obtaining the minimum number of samples, then the proportional sample random sampling was employed to determine the proportional allocation, as follows:

$\mathrm{Ni}=\mathrm{Ni} / \mathrm{N} \times \mathrm{n}$

Description:

$\mathrm{N}$ = sample size

$\mathrm{Ni}=$ population size

$\mathrm{N}=$ overall sample size

$\mathrm{Ni}=$ sample size

Based on the calculation, it was determined then to involve 24 and 23 students from class A and class B, respectively.

\section{Data Collection}

To collect the data in this study, the researcher deployed a questionnaire and documentary analysis.

The items in the Questionnaire on learning interest and motivation, adapted from the Motivated Strategies for Learning Questionnaire (MSLQ, Pintrich \& deGroot, 1990) were prepared with alternative answers of a fivepoint Likert Scale (always, often, sometimes, seldom, never) with a score from 5, 4, 3, 2, to 1 . The questionnaire was developed based on indicators of each of the research variables (interest and motivation), consisting of 60 statements. The items were divided into seven subtopics covering: diligent in doing tasks (11 items), tenacious in facing difficulties (11 items), showing interest in various problems (9 items), preferring to work independently ( 9 items), getting bored on routine tasks (8 items), able to defend one's opinion (8 items), and eager to find and solve problems (4 items). The questionnaire was then validated by expert with the help of SPSS as well.

Data of students' learning outcomes were obtained from the results the final exam's scores of the students in Korean Education Study Program at a state university in Bandung Indonesia, batch 2015.

\section{Significance Test}

To determine the influence between the independent variables (interest and motivation) and the dependent variable (learning outcomes) and to test the hypothesis, regression equation was employed, as follows:

$Y=a 0+\beta 1 X 1+\beta 2 X 2$

With $\mathrm{Y}=$ Learning outcomes; $\mathrm{X} 1=$ interest; $\mathrm{X} 2=$ motivation; $a=$ Constants; and $\beta=$ Regression coefficient.

The hypotheses of the present study are:

$\mathrm{H}_{0}=$ Learning interest and motivation have no significant influence on learning outcomes

$\mathrm{H}_{1}=$ Learning interest and motivation have significant influence on learning outcomes

\section{RESULTS}

The results of the study are elaborated in the following subsections.

\section{Students' Learning Interest and Motivation}

The whole 47 respondents of this research responded to all of the items (60) in the questionnaire. Within the range of $0-300$ as the maximum score, the lowest score of the learning interest and motivation questionnaire for class $A$ was 180 , and 168 for class $B$. The highest scores for class A and B were 260 and 273, respectively. Based on the score categorization, it can be concluded that most of the respondent students had high learning interest and motivation.

For the first subtopic of items in the questionnaire, namely "diligence in doing tasks" (11 items), the item with the highest score was item 9: "When there is an assignment, I will finish it so that I can get a high score." On the other hand, the item with the lowest score was "I prefer to talk to my friends than doing the task/assignment given by the lecturers" (item No. 2), which was a negative statement.

For the topic of "tenacity in facing difficulties" (11 items), the item with the highest score was item no. 21 "I am satisfied if my learning achievements are better than before", and the lowest score was obtained by items no. 16 and 17, namely "I am lazy to study if the course is difficult" and "I do not quickly give up when facing difficulties in doing a task". 
Next is the subtopic of "showing interest in various problems" (9 items), the highest score was for item no. 26 "I will invite friends to discuss if I find difficulty in learning", and the lowest score for item number 29 "I feel tired understanding a material that I consider difficult."

The subsequent subtopic is "preferring to work independently" (9 items). The highest score was obtained by item no. 35: "I will ask a friend to do my assignment if I experience difficulty", and the lowest score was for item no. 37: "When a lecturer cannot make it to the class, I prefer to go playing". This subtopic also received the lowest score of all items in the whole subtopics, with three items gaining an average score of below 3 .

For the subtopic of "easily getting bored on routine tasks" (8 items), question number 48 "I am lazy to attend a lesson with an experiment/modeling" got the highest score, while question 44, "I feel calm if I am given a boring task," received the lowest one.

With regard to the subtopic of "being able to defend one's opinion (8 items), item no. 54 "I will just let it go if the correct answer I gave to my assignment is inaccurately assessed as incorrect" obtained the highest score, and item no. 52 "I am not interested in getting involved in debates in learning" received the lowest score.

Finally, for the subtopic of "being eager to find and solve problems" (4 items), question number 57 "I spend the spare time in between classes by doing exercise or unfinished assignment" and 60 "I will work on the exercise book only when asked by the lecturer" both obtained the lowest score of below 3, and question no. 59 "I am happy to try working on problems/exercise in the packet book, even though the lecturer has not asked to do so" got the highest score.

The detail analysis of the items in the questionnaire confirms the high scores gained by most of the respondents. Most of the "low" average scores were obtained by items with negative statements.

\section{Students' Learning Outcomes}

The next variable under study is learning outcomes. The learning outcomes were obtained from the final exam scores of the students in the subject of language and art appreciation.

The data of students' learning outcomes and their scores on the learning interest and motivation questionnaire are provided in table 1.

Table 1. Students' scores on the three variables

\begin{tabular}{l|ll|l|ll}
\hline \multirow{2}{*}{ Resp. } & \multicolumn{2}{|c|}{ Score } & \multirow{2}{*}{ Resp. } & \multicolumn{2}{c}{ Score } \\
\cline { 2 - 3 } & Quest. & Exam & & Quest. & Exam \\
\hline 1 & 233 & 94 & 25 & 233 & 91.8 \\
\hline 2 & 260 & 72.4 & 26 & 240 & 75.7 \\
\hline 3 & 232 & 71.6 & 27 & 259 & 73.9 \\
\hline 4 & 228 & 75.7 & 28 & 242 & 62.5 \\
\hline 5 & 206 & 77.1 & 29 & 226 & 63.9 \\
\hline 6 & 214 & 57.3 & 30 & 226 & 70.3 \\
\hline 7 & 180 & 87.9 & 31 & 208 & 69 \\
\hline
\end{tabular}

\begin{tabular}{llllll}
\hline 8 & 187 & 57.9 & 32 & 222 & 72.2 \\
\hline 9 & 217 & 86.8 & 33 & 238 & 78.1 \\
\hline 10 & 258 & 64 & 34 & 209 & 64.9 \\
\hline 11 & 229 & 62.7 & 35 & 209 & 81.7 \\
\hline 12 & 238 & 82 & 36 & 216 & 77.5 \\
\hline 13 & 198 & 64.1 & 37 & 227 & 65.1 \\
\hline 14 & 224 & 69.2 & 38 & 168 & 36.6 \\
\hline 15 & 238 & 80.8 & 39 & 223 & 58.6 \\
\hline 16 & 215 & 52.3 & 40 & 189 & 61 \\
\hline \multirow{2}{*}{ Resp. } & Score & Resp. & Score & Resp. & Score \\
\hline 17 & Quest. & Exam & & & Quest. \\
\hline 18 & 205 & 51.6 & 41 & 218 & 79.8 \\
\hline 19 & 221 & 73.8 & 42 & 262 & 75.9 \\
\hline 20 & 206 & 77.2 & 43 & 220 & 73.8 \\
\hline 21 & 180 & 82.8 & 44 & 221 & 59.9 \\
\hline 22 & 170 & 82.5 & 46 & 211 & 72.4 \\
\hline 23 & 241 & 70.8 & 47 & 228 & 70.3 \\
\hline 24 & 206 & 89.7 & & & \\
\hline \multicolumn{7}{l}{} \\
\hline
\end{tabular}

As Table 1 shows, the lowest final exam score for language and art appreciation subject is 36.3 , and the highest score is 94 . Coincidentally, respondent 38 who obtained the lowest final exam score also scored the lowest in the questionnaire (168), signaling a possibility that low learning interest and motivation had an effect on low learning outcomes. However, the students who scored the highest in the questionnaire (respondent 45) did not score the highest in the final exam, although his/her score was still in the "high" category.

Therefore, to determine whether learning interest and motivation simultaneously had influence on learning outcomes of language and art appreciation subject, a significance test was carried out.

\section{Significance Test Result}

The significance test result is shown in Table 2 .

Table 2. Significance test result

\begin{tabular}{|c|c|c|c|c|c|}
\hline \multicolumn{6}{|c|}{ Coefficients $^{\mathrm{a}}$} \\
\hline \multirow[b]{2}{*}{ Model } & Unstand & Coef. & $\begin{array}{l}\text { Stand. } \\
\text { Coef. }\end{array}$ & \multirow[b]{2}{*}{$t$} & \multirow[b]{2}{*}{ Sig. } \\
\hline & B & $\begin{array}{l}\text { Std. } \\
\text { Error }\end{array}$ & Beta & & \\
\hline 1 (Constant) & .661 & .268 & .345 & 2.465 & .018 \\
\hline Score & 173.912 & 19.424 & & 8.954 & .000 \\
\hline
\end{tabular}

a. Dependent Variable: Learning Outcomes (Final Exam)

Based on the test results displayed in Table 2, the value of $\mathrm{t}=8.954$ at the sig. value of 0.000 (it means that the value of sig is <0.05). It can be concluded that $\mathrm{Ho}$ is rejected and $\mathrm{H}_{1}$ is accepted, meaning the interest and motivation scores had significant influence on the final exam's scores. In other words, the results of this research show that learning interest and motivation determined learning outcomes, especially in the subject of language and art appreciation. 


\section{DISCUSSION}

This study found that the high level of interest and motivation determined the learning outcomes of students in the subject of language and art appreciation.

The results of this research are in line with those of Bye, Pushkar, and Conway (2007), Eom, Wen, and Ashill (2006), and Muller \& Louw (2004) in which learning interest and motivation, either separately or simultaneously had influence on students' learning outcomes in various subjects and contexts.

This result can be explained by the theories put forward by experts. According to Gie (in Hidi \& Renninger, 2006), high interest in learning will greatly affect the way learners learn; for example, a learner who wants to get good learning outcomes will learn earnestly by focusing on the lesson. Thus, a high interest in learning will affect the process of successful teaching and learning activities. With the interest in learning, learners can be more focused on the lessons, and they will be more easily attached to the lessons and do not quickly get bored while studying (Silvia, 2008).

Especially in the general subject of language and art appreciation that does not specifically offer lessons or materials on Korean language as the students' major, interest and motivation in learning are needed in order to succeed in gaining good learning outcomes. The present research shows that students with high interest learning and motivation tended to have greater final exam scores for the subject of language and art appreciation than the students with rather low interest and motivation in learning.

\section{CONCLUSIONS}

Based on the results of this research, some conclusions can be drawn. First, learning interest can be expressed through students' preferences of certain lesson or methods. Every learner always has an interest to learn, no matter how low the interest is. Therefore, teachers or lecturers should be able to arouse the interest of learners. Teachers should be able to make learners happy in learning. With the interest that arises, learners will try better with the lessons, and hopefully learners will get good learning outcomes.

Elements that affect the motivation in learning include aspirations of the soul, the ability of learners, the condition of learners, environmental conditions of learners, dynamic elements in learning, and efforts of teachers in learning.

Future researchers can conduct similar research to a larger number of samples and with different academic levels, or by using other elements that may affect student learning outcomes. As this study limited the learning outcomes to students' final scores, future researchers may also expand the definition of learning outcomes to those based on qualitative assessment.

\section{ACKNOWLEDGEMENT}

Appreciation and thanks the researchers express to Prof. Dr. Ahman as Head of LPPM UPI for making this research possible through the funding of Affirmation
Program. Our sincere gratitude also goes to Didin Samsudin (Head of Korean Education Study program), Velayeti Nurfitriana Ansas (Lecturer at Korean Education Study Program), and students of Korean Education Study Program FPBS UPI batch 2015 for their support and participation.

\section{REFERENCES}

Asim, S., Chase, R. S., Dar, A., \& Schmillen, A. (2016). Improving learning outcomes in South Asia: Findings from a decade of impact evaluations. Policy Research Working Paper 7362, World Bank Group, 1-32. https://doi.org/10.1093/wbro/lkw006

Biggs, J. (2012). What the student does: Teaching for enhanced learning. Higher Education Research \& Development, 31(1), 39-55. https://doi.org/10.1080/0729436990180105

Burke, J. (1995). Outcomes, learning and the curriculum: Implications for NVQs, GNVQs and other qualifications. London: The Falmer.

Bye, D., Pushkar, D., \& Conway, M. (2007). Motivation, interest, and positive affect in traditional and nontraditional undergraduate students. Adult Education Quarterly, 57(2), 141-158.

Cheak, M., \& Wessel, J. (2005). Motivation. Illinois Reading Council Journal, 33(3), 60-62. https://doi.org/Article

Dansereau, R. A. (1969). Motivating students. Community and Junior Colleges, 17(2), 110-111. https://doi.org/10.1177/108056990306600408

Eom, S. B., Wen, H. J., \& Ashill, N. (2006). The determinants of students' perceived learning outcomes and satisfaction in University online education: an empirical investigation. Decision Sciences Journal of Innovative Education, 4(2), 215-235.

Fahrmeir, L., Pigeot, I., Künstler, R., \& Tutz, G. (2004). Statistik. Der Weg Zur Datenanalyse. Retrieved from

http://books.google.de/books?id=ZinjP103iRcC\&a $\mathrm{mp}$;printsec=frontcover\&amp;dq=inauthor:Fahrmei r+Ludwig+intitle:Statistik\&amp;hl=\&amp;cd=1\&am p;source=gbs_api

Frankola, K. A., Flora, A. L., Torres, A. K., Grissom, E. M., Overstreet, S., \& Dohanich, G. P. (2010). Effects of early rearing conditions on cognitive performance in prepubescent male and female rats. Neurobiology of Learning and Memory, 94(1), 91-99. https://doi.org/10.1016/j.nlm.2010.04.005

Muller, F. H., \& Louw, J. (2004). Learning environment, motivation, and interest: perspectives on selfdetermination theory. Psychological Society of South Africa, 34(2), 169-190.

Hamalik, O. (2005). Proses belajar mengajar. Jakarta: Bumi Aksara.

Hanrahan, M. (2000). The effect of learning environment factors on students' motivation and learning. International Journal of Science Education, 20(6), 737-753. https://doi.org/10.1080/0950069980200609 
Harun, H. (2006). Minat, motivasi dan kemahiran mengajar guru pelatih. Jurnal Pendidikan, 31, 8396.

Hidi, S., \& Renninger, K. A. (2006). The four-phase model of interest development. Educational Psychologist, 41(2), 111-127. https://doi.org/10.1207/s15326985ep4102_4

Maslow, A. H. (1955). Motivation and personality. Motivation and Personality., 62-27. https://doi.org/10.1037/h0039764

O'Neil, H., Wainess, R., \& Baker, E. L. (2005). Classification of learning outcomes: Evidence from the computer games literature. The Curriculum Journal, 16(4), 455-474. https://doi.org/10.1080/09585170500384529

Ormrod, J. E. (2006). Educational psychology: Developing learners. Upper Saddle River, NJ: Pearson Merrill Prentice Hall.

Pintrich, P. R., \& deGroot, E. V. (1990). Motivational and self-regulated learningcomponents of classroom academic performance. Journal of EducationalPsychology, 82, 33-40.

Sardiman, A. M. (2011). Interaksi dan motivasi belajar mengajar. Jakarta: Rajawali Press.

Sari, A. R. (2009). Media pembelajaran. Palembang: Rajawali Pers.

Silvia, P. J. (2008). Interest-The curious emotion. Current Directions in Psychological Science, 17(1), 57-60. https://doi.org/10.1111/j.14678721.2008.00548.x

Slameto. (2010). Belajar dan faktor faktor yang mempengaruhi. Jakarta: Rineka Cipta.

Sogunro, O. A. (2014). Motivating factors for adult learners in higher education. International Journal of Higher Education, 4(1), 22-37. https://doi.org/10.5430/ijhe.v4n1p22

Tella, A. (2007). The impact of motivation on students' academic achievement and learning outcomes in mathematics among secondary school students in Nigeria. Learning, 3(2), 149-156.

Wenger, E. (1997). Practice, learning, meaning, identity. Training, 34(2), 38-39. https://doi.org/10.2277/0521663636

Yamane, T. (1973) Statistics: An introductory analysis. $3^{\text {rd }}$ Edition. New York: Harper and Row. 